\title{
ANALISIS DAMPAK LIBERALISASI PERDAGANGAN KAWASAN EKONOMI ASIA TERHADAP KINERJA EKONOMI MAKRO ASEAN
}

\author{
Ichsan Zulkarnaen ${ }^{1}$, Rina Oktaviani ${ }^{2}$, Mangara Tambunan ${ }^{3}$, Yulius $^{4}$ \\ ${ }^{1}$ Mahasiswa Pascasarjana \\ Institut Pertanian Bogor \\ ${ }^{2}$ Departemen Ilmu Ekonomi \\ Institut Pertanian Bogor \\ ${ }^{3}$ Institut Pertanian Bogor \\ ${ }^{4}$ Institut Pertanian Bogor
}

Artikel diterima Juni 2012

Artikel disetujui untuk dipublikasikan Desember 2012

\section{ABSTRACT}

This research intends to explore the impact of trade liberalization on macroeconomic performances, especially on Indonesia and other ASEAN Countries. The GTAP model is used as the main tool of analysis. The findings show that the benefit of the trade liberalization is still dominated by developed countries such as Japan and China. The elimination of import tariff results an increase in economic growth and economic welfare on all participated countries. It also results in an increase in GDP deflator and terms of trade which meant decreasing competitiveness.

Keywords: Asia trade liberalization, ASEAN countries, GTAP model

\section{ABSTRAK}

Penelitian ini bertujuan untuk mengetahui dampak dari liberalisasi perdagangan terhadap kinerja makroekonomi, khususnya di Indonesia dan negara-negara ASEAN lainnya. Alat utama dalam analisis penelitian ini yaitu dengan menggunakan model GTAP. hasil penelitian menunjukkan bahwa manfaat dari adanya liberalisasi perdagangan masih didominasi oleh negara-negara maju seperti Jepang dan Cina. Dengan adanya penghapusan tarif impor menyebabkan peningkatan pertumbuhan dan kesejahteraan ekonomi di semua negara-negara yang berpartisipasi dalam kebijakan tersebut. Hal ini juga mengakibatkan peningkatan PDB deflator dan term of trade syarat-syarat perdagangan yang berarti penurunan daya saing.

Kata Kunci : Liberalisasi Perdagangan Asia, Negara-negara ASEAN, Model GTAP

\section{Pendahuluan}

\subsection{Latar Belakang}

Dalam dua dasawarsa terakhir perkembangan perekonomian dunia telah mengalami setidaknya dua perubahan yang signifikan. Pertama, bergesernya titik berat perekonomian dari kawasan Eropa dan Amerika ke kawasan Asia Pasifik khususnya Asia Timur seperti Jepang, Korea dan Cina (Haryadi, 2008). Kedua, semakin terbukanya perekonomian dunia yang ditandai dengan semakin banyaknya negara-negara yang memilih untuk ikutserta dalam perekonomian terbuka, yang memungkinkan kegiatan ekspor dan impor dilakukan secara lebih terbuka, baik pada aliran barang dan jasa, investasi, modal, dan sumberdaya manusia.

Derajad keterbukaan yang semakin tinggi sejak dua dekade terakhr ini memberikan dampak saling ketergantungan antarnegara dalam 
perekonomian baik di sisi makro maupun sektoral. Walaupun negara-negara yang terlibat dalam skema perdagangan bebas meyakini adanya manfaat yang akan diperoleh, namun proses perdagangan bebas yang melibatkan banyak negara (multilateral) tentu tidaklah mudah seperti halnya perjanjian perdagangan bebas dalam naungan WTO. Lambatnya

kemajuan dalam perjanjian WTO menyebabkan beberapa negara termasuk Indonesia mencari alternatif kerjasama perdagangan melalui kerjasama bilateral dan regional dalam bentuk Free Trade Agreement (FTA). Indonesia sendiri yang tergabung dalam forum kerjasama ASEAN telah sepakat untuk membentuk FTA dan Economic Partnership Agreement (EPA) antara lain dengan negara-negara China, Korea, Jepang dan India.

Seperti yang kita ketahui bahwa negara-negara di kawasan ASEAN dan negara-negara di kawasan Asia lainnya seperti China, Jepang dan Korea merupakan mitra dagang utama Indonesia. Pada tahun 2010 saja pangsa pasar ekspor non migas Indonesia ke Jepang mencapai 12,7 persen. Sedangkan pangsa pasar ekspor Indonesia ke China mencapai 10,8 persen. Sementara pangsa ekspor non migas Indonesia ke Amerika Serikat hanya 10,3 persen. Untuk kawasan ASEAN Singapura, Malaysia dan Thailand menjadi mitra dagang utama dengan pangsa ekspor masing-masing mencapai 7,4 persen; 6,0 persen dan 3,1 persen.

Gambaran tersebut menunjukkan bahwa perdagangan bilateral Indonesia didominasi oleh negara-negara di kawasan ASEAN dan Asia. Sehingga sangat menarik untuk dikaji dampak dari liberalisasi ASEAN dengan negara-negara di luar ASEAN yakni China, Korea, Jepang dan India terhadap ekonomi Indonesia dan negara-negara yang terlibat didalamnya.

\subsection{Perumusan Masalah}

Hingga kini perdebatan ilmiah mengenai dampak liberalisasi masih terus terjadi. Menurut pendapat sebagian pakar ekonomi, perdagangan antar negara sebaiknya dibiarkan secara bebas dengan seminimal mungkin diterapkan hambatan baik tarif maupun hambatan non-tarif. Keterbukaan diyakini akan mendorong suatu negara lebih fokus menghasilkan produk-produk yang memiliki keunggulan komparatif sehingga akan lebih efisien yang pada gilirannya berdampak positif terhadap perekonomian secara keseluruhan.

Hal ini sejalan dengan beberapa studi terdahulu yang menyatakan bahwa perdagangan yang lebih bebas akan memberikan manfaat bagi negara pelaku dan dunia. Hasil penelitian yang ditunjukkan oleh Hadi (2003), yang juga menjelaskan bahwa selain meningkatkan distribusi kesejahteraan antar negara, liberalisasi perdagangan juga akan meningkatkan kuantitas perdagangan dunia dan efisiensi ekonomi.

Namun demikian, oleh karena terdapat perbedaan penguasaan sumberdaya yang menjadi komponen pendukung daya saing, sebagian pakar yang lain berpendapat bahwa manfaat positif dari liberalisasi tidak dapat dinikmati secara proporsional oleh semua negara bahkan berpotensi menimbulkan dampak negatif. Studi yang dilakukan oleh Nayyar (1997) menyebutkan bahwa keuntungan-keuntungan dari liberalisasi perdagangan menumpuk hanya di sebagian kecil negara sedang berkembang yakni negara-negara yang masuk dalam kategori lebih maju seperti Thailand, Korea dan China.

Studi Feridhanusetyawan dan Rizal (1998) menunjukkan bahwa dengan lebih terbukanya perdagangan internasional akan diperoleh tambahan kesejahteraan ekonomi dalam bentuk equivalent variation yang semakin tinggi. Namun kesejahteraan tersebut tidak dapat dinikmati sama oleh semua negara. Bahkan negara yang termasuk kategori 
wilayah lainnya (Asia Selatan, Afrika, Argentina, Brasil, Amerika Latin lainnya, sebagian Eropa, Timur Tengah, dan bekas negara-negara Uni Soviet) mengalami dampak negatif. Hal ini didukung oleh sejumlah penelitian antara lain Wijaya (2000) dan Oktaviani (2000) yang membuktikan bahwa dampak positif yang ditimbulkan keterbukaan ekonomi terhadap perekonomian setiap negara tidaklah sama.

Dampak liberalisasi perdagangan terhadap perekonomian Indonesia juga telah banyak dilakukan seperti yang dilakukan oleh Ratnawati (1996) serta Oktaviani, et al (2007) yang masingmasing menunjukan perbedaan hasil.

Menggunakan pendekatan

Keseimbangan Umum, Ratnawati (1996) mengkaji apakah penurunan tarif impor dan pajak ekspor dapat memperbaiki kinerja perekonomian Indonesia serta distribusi pendapatan dari faktor produksi dan rumah tangga. Secara umum diketahui bahwa penurunan tarif impor dan pajak ekspor akan meningkatkan kinerja perekonomian Indonesia yang dicerminkan dari peningkatan PDB riil serta apresiasi nilai tukar rupiah terhadap dolar Amerika Serikat.

Penelitian Oktaviani, et al (2007) menganalisis FTA dalam skema ASEAN Plus One yakni ASEAN-China dan ASEAN-Korea yang hasilnya menunjukkan total GDP negara-negara ASEAN meningkat relatif kecil dibandingkan dengan negara-negara China dan Korea. Peningkatan GDP lebih banyak didorong oleh konsumsi masyarakat, sedangkan peningkatan investasi relatif rendah. Hal ini tentunya kurang baik apabila dilihat dalam perspektif jangka panjang.

Dengan latar belakang bahwa Indonesia telah terlibat dalam forum kerjasama perdagangan khususnya kerjasama regional ASEAN-China, ASEAN-Korea, ASEAN-Jepang dan ASEAN-India dan berdasarkan identifikasi masalah diatas bahwa dampak dari liberalisasi perdagangan berbeda di masing-masing negara yang terlibat, maka penulis merumuskan permasalahan sebagai berikut: Bagaimana dampak dari liberalisasi perdagangan dalam skema : ASEAN-China, ASEAN-Korea, ASEANJepang, ASEAN-India, ASEAN-Asia terhadap perekonomian makro Indonesia dan negara-negara yang terlibat di dalamnya.

\subsection{Tujuan Penelitian}

Secara umum penelitian ini bertujuan untuk menganalisa kinerja perekonomian Indonesia sebagai akibat dari adanya perubahan tata ekonomi dunia serta kebijakan ekonomi dalam negeri yang terkait dengan liberalisasi perdagangan. Secara khusus penelitian ini bertujuan untuk menganalisa dampak liberalisasi perdagangan terhadap ekonomi makro negara-negara yang terlibat didalamnya. Skema liberalisasi yang dianalisis adalah : ASEAN-China, ASEAN-Korea, ASEAN-Jepang, ASEANIndia dan ASEAN-Asia.

\subsection{Ruang Lingkup Penelitian}

1. Penelitian ini difokuskan pada pada negara-negara yang tercakup dalam kerjasama ASEAN ditambah 4 negara di kawasan Asia lainnya yakni China, Jepang, Korea Selatan dan India. Bersama-sama dengan Hongkong dan Taiwan, empat negara terakhir dalam penelitian ini disebut Asia).

2. Kinerja ekonomi makro yang akan dianalisis mencakup PDB riil, PDB deflator, tingkat kesejahteraan, terms of trade, dan ekspor bersih.

\section{Kondisi Ekonomi Makro Indonesia dan Negara-Negara Di Kawasan Asean}

Secara keseluruhan, gambaran ekonomi Indonesia sebelum dan setelah krisis mengalami perubahan. Paska krisis ekonomi tahun 1997/ 1998, pola pertumbuhan ekonomi mengalami perubahan sebagai berikut. 
Pertama, sektor industri kurang berperan sebagai penggerak ekonomi. Dalam tahun 1999-2010, industri pengolahan hanya tumbuh 4,6 persen per tahun, lebih rendah dibandingkan dengan rata-rata pertumbuhan PDB sebesar 5,1 persen. Pertumbuhan ekonomi paska krisis lebih didorong oleh sektor tersier seperti pengangkutan dan telekomunikasi. Sementara itu, perlambatan pertumbuhan industri pengolahan non-migas terjadi pada hampir semua kelompok industri berbasis ekspor seperti makanan,minuman dan tembakau; tekstil, serta barang kulit dan alas kaki.

Kedua, sektor pertanian tumbuh rendah dimana dalam tahun 1999 - 2010 sektor pertanian hanya tumbuh 3,4 persen dibandingkan periode 1968-1997 yang tumbuh 3,5 persen. Gambaran pertumbuhan ekonomi beserta struktur ekonominya dapat dilihat pada tabel berikut.

\begin{tabular}{|lcc|}
\hline \multicolumn{3}{|c|}{ Tabel 1 } \\
\multicolumn{2}{|c}{$\begin{array}{c}\text { Rata - Rata Pertumbuhan Ekonomi Tahun 1968 - 2010 } \\
\text { (persen perubahan) } \\
\text { Sebelum Krisis } \\
1968-1997\end{array}$} & $\begin{array}{c}\text { Paska Krisis } \\
1999-2010\end{array}$ \\
\hline PDB riil & $\mathbf{6 , 8}$ & $\mathbf{5 , 1}$ \\
\hline Primer & 3,5 & 3,4 \\
Pertanian & 6,0 & 1,8 \\
Pertambangan dan Penggalian & 10,9 & 4,6 \\
Industri Pengolahan & 11,1 & 5,2 \\
- Industri Pengolahan Non-Migas & 13,0 & \\
Tersier & 12,9 & 8,4 \\
Listrik, Gas, dan Air Bersih & 8,2 & 6,6 \\
Bangunan & 9,3 & 11,5 \\
Perdagangan, Hotel, Restoran & 10,8 & 5,9 \\
Pengangkutan dan Komunikasi & 5,8 & 5,1 \\
Keuangan, Persewaan, Jasa Usaha &
\end{tabular}

Sumber: Diolah dari Badan Pusat Statistik (BPS)

Selain mengalami perubahan struktur ekonomi, proses pemulihan ekonomi Indonesia juga dirasakan lambat bila dibandingkan dengan pertumbuhan ekonomi negara-negara se-kawasan yang terkena krisis seperti Malaysia, Thailand serta Korea Selatan. Pada tahun 2010 saja perekonomian Indonesia tumbuh di bawah 7 persen yang berarti jauh dibawah pertumbuhan negara-negara ASEAN lainnya seperti Malaysia, Thailand dan Philipina yang tumbuh diatas 7 persen.

\begin{tabular}{|cccc|}
\hline \multicolumn{5}{c|}{ Tabel 2 } \\
Pertumbuhan Ekonomi Negara-Negara ASEAN Lainnya \\
Saat dan Setelah Krisis (\%) \\
\hline Negara & $\mathbf{1 9 9 8}$ & $\mathbf{2 0 0 4}$ & $\mathbf{2 0 1 0}$ \\
& 5,0 & 10,3 & 6,0 \\
Kamboja & $-7,4$ & 6,8 & 7,2 \\
Malaysia & 5,8 & 13,6 & 5,3 \\
Myanmar & $-0,6$ & 6,4 & 7,3 \\
Filipina & $-1,4$ & 9,3 & 14,5 \\
Singapura & $-10,5$ & 6,3 & 7,8 \\
Thailand & 5,8 & 7,8 & 6,8 \\
Vietnam & &
\end{tabular}

Sumber: Diolah dari Badan Pusat Statistik (BPS) 
Demikian pula dengan tingkat inflasi yang merupakan salah satu indikator stabilitas ekonomi. Pada tahun 2010 laju inflasi di Indonesia masih diatas 5 persen, sedangkan laju inflasi di Malaysia, Thailand dan Philipina yang berkisar 2-3 persen saja. Hal ini menunjukkan mahalnya harga barang barang domestik di Indonesia dan inefisiensi dalam produksi. Perkembangan inflasi negara-negara di kawasan ASEAN pada umumnya dapat dilihat dalam tabel berikut.

\begin{tabular}{|cccc|}
\hline \multicolumn{5}{c|}{ Tabel 3 } \\
Laju Inflasi Beberapa Negara-Negara ASEAN \\
\\
Saat dan Setelah Krisis (\%)
\end{tabular}

Sumber: Diolah dari Badan Pusat Statistik (BPS)

Kestabilan nilai inflasi tentunya menjadi salah satu indikator yang memberikan gambaran kepada perekonomian dunia bahwa suatu negara dalam kondisi yang positif dan mampu memberikan kepastian usaha bagi para investor asing yang ingin menanamkan modalnya. Hal ini sejalan dengan masih terbatasnya arus investasi Indonesia dibandingkan negara-negara lain di kawasan ASEAN.

\begin{tabular}{|c|c|c|c|}
\hline \multicolumn{4}{|c|}{$\begin{array}{l}\text { Tabel } 4 \\
\text { Nilai FDI di beberapa negara di kawasan Asia } \\
\text { (US\$ Juta) }\end{array}$} \\
\hline \multirow[t]{2}{*}{ Negara } & \multicolumn{3}{|c|}{ Periode } \\
\hline & 1998 & 2004 & 2008 \\
\hline Kamboja & 242,9 & 131,4 & 815,2 \\
\hline Indonesia & -356 & 1894,5 & $8.339,80$ \\
\hline Malaysia & 2.745 & 4623,9 & $8.050,00$ \\
\hline Myanmar & 683,4 & 251,1 & 714,8 \\
\hline Filipina & $2.271,6$ & 688,0 & $1.520,00$ \\
\hline Singapura & $7.594,3$ & 20052,2 & $22.801,80$ \\
\hline Thailand & $7.491,2$ & 5862,0 & $9.834,50$ \\
\hline Vietnam & $1.700,0$ & 1610,1 & $8.053,00$ \\
\hline
\end{tabular}

Sumber: Diolah dari Badan Pusat Statistik (BPS)

Dengan latar belakang kondisi perekonomian nasional yang masih rentan dan belum sepenuhnya pulih dari krisis yang telah dikemukakan, permasalahan yang muncul sekarang adalah dalam posisi ekonomi yang relatif tidak terlalu baik dengan daya saing yang rendah dibandingkan dengan negara-negara lain apakah liberalisasi perdagangan akan memperburuk kondisi perekonomian Indonesia? 


\section{Metodologi Penelitian}

Alat analisa utama yang akan digunakan dalam penelitian ini adalah keseimbangan umum dengan model GTAP (General Trade Analysis Project) versi 7.0 dengan pertimbangan bahwa model ini dapat digunakan untuk melihat dampak dari suatu kebijakan terhadap perekonomian di banyak negara secara simultan. Data yang digunakan dalam penelitian ini berupa data sekunder yang berasal dari basis data GTAP (General Trade Analysis Project) versi 7.0

Data sekunder lainnya diperoleh dari berbagai publikasi resmi lembaga maupun instansi terkait diantaranya: International Financial Statistics, Statistical Yearbook of Indonesia (BPS) serta Indikator Ekonomi (BPS)

Adapun simulasi kebijakan yang dianalisis untuk menjawab tujuan penelitian ini adalah penurunan tarif impor sampai 0 persen secara serentak untuk semua komoditas yang terpilih di negara yang terlibat kemudian akan dilihat dampaknya skema liberalisasi ASEANChina, ASEAN-Korea, ASEAN-Jepang, ASEAN-India dan ASEAN-Asia secara makro ekonomi.

\section{Kondisi Aliran Perdagangan Dan Tarif Antar Negara Asean Dan Asia Lainnya}

Sebelum menganalisis kinerja ekonomi makro Indonesia, terlebih dahulu akan digambarkan kondisi aliran perdagangan dan kondisi tarif yang sedang berlaku antar negara ASEAN dan beberapa negara Asia lainnya (China, Jepang dan Korea) sebelum diberlakukannya Free Trade Area (FTA). Dimana data aliran perdagangan dan tarif yang sedang berlaku tersebut keseluruhannya bersumber dari GTAP Data Base versi 7.0.

\begin{tabular}{|c|c|c|c|c|c|c|c|c|c|c|}
\hline \multicolumn{11}{|c|}{ Tabel 5. ALIRAN EKSPOR ANTAR NEGARA ASEAN-CHINA-KOREA-JEPANG (US\$ Juta) } \\
\hline \multirow{11}{*}{ 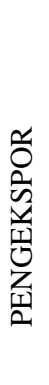 } & & & & & PENG & MPOR & & & & \\
\hline & & Indonesia & Malaysia & Philipina & Singapura & Thailand & China & Jepang & Korea & Total \\
\hline & Indonesia & 0 & $3,365,5$ & 1185,2 & $6.877,9$ & $2.211,5$ & $8.124,0$ & $14.088,9$ & $4.742,6$ & $40.596,7$ \\
\hline & Malaysia & $2.574,4$ & 0 & $1.085,0$ & $15.699,1$ & $5.768,4$ & $22.587,8$ & $13,953,0$ & $4.396,5$ & $66.784,2$ \\
\hline & Philipina & 395,8 & $2.544,5$ & 0 & $3.067,2$ & $1.383,7$ & $5.417,9$ & $8.596,9$ & $2.447,2$ & $23.853,1$ \\
\hline & Singapura & $10.435,7$ & $13.256,8$ & $2.889,9$ & 0 & $4.590,6$ & $16.600,2$ & $9.039,8$ & $6.138,7$ & $62.951,7$ \\
\hline & Thailand & $2.854,1$ & $5.587,3$ & $1.790,9$ & $4.944,4$ & 0 & $14.437,2$ & $14,546,3$ & $2.673,9$ & $46.834,0$ \\
\hline & China & $8.277,2$ & $9.546,4$ & $5.364,8$ & $13.184,7$ & $7.514,8$ & 0 & $89.210,3$ & $28.902,3$ & $162.000,4$ \\
\hline & Jepang & $9.214,2$ & $13.262,4$ & $9.015,5$ & $16.019,4$ & $19,985,6$ & $93.356,2$ & 0 & $48.426,3$ & $209.189,7$ \\
\hline & Korea & $3.710,5$ & $5.529,9$ & $3,231,1$ & $4.939,4$ & $3.650,3$ & $66.399,3$ & $24.462,5$ & 0 & $111.922,9$ \\
\hline & Total & $37.371,9$ & $53.093,7$ & $25.282,5$ & $64.732,0$ & $45.104,9$ & $226.922,6$ & $173.897,8$ & $97.727,4$ & $724.132,6$ \\
\hline
\end{tabular}

\begin{tabular}{|c|c|c|c|c|c|c|c|c|c|c|}
\hline \multicolumn{11}{|c|}{ Tabel 6. ALIRAN IMPOR ANTAR NEGARA ASEAN-CHINA-KOREA-JEPANG } \\
\hline \multirow{10}{*}{ 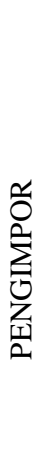 } & & \multicolumn{9}{|c|}{ PENGEKSPOR } \\
\hline & & Indonesia & Malaysia & Philipina & Singapura & Thailand & China & Jepang & Korea & Total \\
\hline & Indonesia & 0 & $3.947,7$ & $1.324,7$ & $7.311,7$ & $2.507,7$ & $9.582,5$ & $15.467,4$ & $5.405,9$ & $45.556,3$ \\
\hline & Malaysia & $2.805,1$ & 0 & $1.932,7$ & $16.356,0$ & $6.320,7$ & $24.405,0$ & $14.950,9$ & $4.757,8$ & $71.528,1$ \\
\hline & Philipina & 418,7 & $2.648,4$ & 0 & $3.158,6$ & $1.541,4$ & $5.741,5$ & $9,243,6$ & $2.648,8$ & $25.396,9$ \\
\hline & Singapura & $11.162,5$ & $14.063,4$ & $3.037,2$ & 0 & $4.987,6$ & $17.943,9$ & $9.338,2$ & $6.369,6$ & $66.902,5$ \\
\hline & Thailand & 3.287 .2 & $6.101,1$ & $1.973,5$ & $5.190,4$ & 0 & $16.320,5$ & $16.320,5$ & $3.241,4$ & $52.658,9$ \\
\hline & China & $9.307,4$ & $10.841,5$ & $6.008,1$ & $13.725,0$ & $8.845,0$ & 0 & $98.808,6$ & $33.305,1$ & $180.840,6$ \\
\hline & Jepang & $10.151,3$ & $15.256,3$ & $9.634,7$ & $16.576,7$ & $23.598,1$ & $104.406,6$ & 0 & $52.671,6$ & $232.295,2$ \\
\hline & Korea & $4.149,4$ & $6.313,0$ & $3.454,8$ & $5.076,3$ & $4.291,3$ & $74.732,9$ & $25.995,4$ & 0 & $124.013,0$ \\
\hline
\end{tabular}




\begin{tabular}{|lcccccccc|}
\hline \multicolumn{7}{c|}{ Tabel 7. TARIF IMPOR ANTAR NEGARA ASEAN DAN ASIA } \\
\hline Negara & Indonesia & Malaysia & Philipina & Singapura & Thailand & China & Jepang & Korea \\
Indonesia & 0 & 6,62 & 2,43 & 0 & 8,47 & 6,50 & 1,37 & 17,67 \\
Malaysia & 2,30 & 0 & 2,01 & 0 & 9,10 & 6,81 & 1,75 & 6,91 \\
Philipina & 1,79 & 14,96 & 0 & 0 & 6,38 & 7,13 & 2,17 & 7,79 \\
Singapura & 3.01 & 4,14 & 1.8 & 0 & 6,86 & 7,23 & 1,73 & 8,85 \\
Thailand & 3,97 & 2,37 & 2,91 & 0 & 0 & 7,62 & 3,22 & 13,35 \\
China & 5,37 & 8,73 & 6,14 & 0 & 13,16 & 0 & 2,94 & 11,98 \\
Jepang & 5,56 & 10,61 & 4,83 & 0 & 14,72 & 8,61 & 0 & 8,13 \\
Korea & 6,08 & 11,66 & 5,18 & 0 & 15,78 & 8,32 & 3,14 & 0 \\
\hline
\end{tabular}

Dari tabel diatas terlihat bahwa negara Jepang adalah negara tujuan utama ekspor Indonesia diikuti oleh Cina dan Singapura. Nilai ekspor Indonesia ke Jepang berdasarkan data dasar GTAP versi 7.0 adalah sebesar US\$ $14.088,9$ juta, sementara ke China sebesar US\$ 8.124 juta dan ke Singapura sebesar US\$6.877,9 juta. Sementara itu impor terbesar Indonesia juga berasal dari Jepang, Cina dan Singapura. Dimana nilai impor dari Jepang mencapai US\$ 15.467,4 juta, sementara impor dari China dan Singapura masing-masing mencapai US\$ 9.585,2 juta dan US\$ 7.317,7 juta.

Berdasarkan data diatas tersebut menunjukkan bahwa Indonesia lebih banyak mengimpor daripada mengekspor. Dimana nilai total ekspor Indonesia ke ASEAN Plus Three mencapai US\$ 40.596,7 juta sedangkan nilai impornya mencapai US\$ 45.556,3 juta. Hal ini menunjukkan bahwa sebelum terjadi skema liberalisasi, Indonesia telah mengalami defisit neraca perdagangan sebesar US\$ 4,959.60.

Indonesia. Dari lima skema liberalisasi yang ada, pertambahan pertumbuhan PDB riil Indonesia berada pada kisaran 0,06 persen dan 0,19 persen dimana pertambahan terendah terjadi pada skema ASEAN-China, dan tertinggi pada skema ASEAN-Asia. Dibandingkan dengan negara-negara di kawasan lainnya, pertambahan pertumbuhan PDB riil di Indonesia tergolong cukup rendah. Rendahnya dampak liberalisasi perdagangan terhadap pertambahan pertumbuhan PDB riil di Indonesia antara
Sementara itu, tarif impor yang berlaku antar sesama negara ASEAN dan negara-negara China, Korea dan Jepang ditunjukkan pada tabel 7. Dari data tersebut terlihat bahwa tarif di Malaysia, Thailand dan Rep Korea masih relatif lebih besar dari pada di negara lain. Indonesia terkena tarif impor paling besar adalah di negara Rep. Korea, Thailand dan Malaysia, sedangkan Indonesia mengenakan tarif paling besar adalah dari negara Rep. Korea, Jepang dan Cina.

\section{HASIL PEMBAHASAN 5.1 Dampak terhadap Pertumbuhan PDB Riil.}

Jika dilihat dampak liberalisasi perdagangan dalam semua skema terhadap performa pertumbuhan nasional, maka secara keseluruhan terjadi peningkatan Produk Domestik Bruto (PDB) riil di semua negara ASEAN. Rata-rata pertambahan pertumbuhan PDB riil tertinggi terjadi pada skema ASEAN-Asia yang mencapai 1,22 persen.

lain karena rendahnya tarif bilateral antara Indonesia dan negara-negara lain baik di kawasan ASEAN maupun Asia sebelum adanya liberalisasi perdagangan (lihat tabel $6.5)$.

Selain itu berdasarkan studi yang dilakukan Swindi (2010) tingkat keterbukaan ekonomi memiliki hubngan positif dengan pertumbuhan ekonomi. Dalam kasus Indonesia, dibandingkan dengan negara-negara lain, tingkat keterbukaan ekonomi Indonesia tidaklah terlalu tinggi. Studi Swindi (2010) 
menunjukkan tingkat keterbukaan ekonomi Indonesia tahun 2003 sebesar 45 persen dan hanya mencapai 53 persen pada tahun 2008. Hal ini mengindikasikan bahwa pertumbuhan ekonomi Indonesia lebih didorong oleh kekuatan domestik

Malaysia. Dari lima skema liberalisasi yang ada, rata-rata pertambahan pertumbuhan PDB riil Malaysia berada pada kisaran 0,04 persen dan 1,16 persen dimana pertambahan terendah terjadi pada skema ASEAN-India, dan tertinggi pada skema ASEAN-Asia. Bila dibandingkan dengan Indonesia maka pertambahan pertumbuhan PDB riil di Malaysia tergolong cukup tinggi. Hal ini didorong antara lain masih tingginya tarif bilateral yang diterapkan oleh negara Malaysia.

Selain itu, besarnya dampak liberalisasi perdagangan terhadap pertambahan pertumbuhan PDB riil Malaysia merupakan refleksi dari keberlanjutan kebijakan pertumbuhan yang didorong oleh ekspor (export-led growth) dimana tingkat keterbukaan ekonomi Malaysia mencapai 179 persen pada tahun 2008.

Singapura. Negara ini tidak terlalu menikmati liberalisasi perdagangan di kawasan ASEAN dan Asia. Pertambahan pertumbuhan PDB riil Singapura tidak terlalu tingggi bakan relatif tetap. Hal ini disebabkan tarif yang diterapka di negara Singapura sudah sedemikian rendanya bahkan terlah mencapai nol persen.

Selain itu struktur ekonomi Singapura yang lebih menekankan pada industri berbasis jasa dibandingkan industri manufaktur membuat liberalisasi perdagangan yang lebih menekankan pada industri manufaktur (barang-barang) tidak terlalu meberi dampak terhadap keseluruhan perekonomian Singapura.

Philipina. Serupa dengan Indonesia, dampak dari liberalisasi perdagangan terhadap pertambahan pertumbuhan PDB riil tidak terlalu dirasakan negara Philipina. Berdasarkan hasil analisa dari kelima skema liberalisasi tersebut, maka pertambahan pertumbuhan PDB riil Philipina berkisar antara yang terendah mencapai 0,15 persen (ASEANIndia) hingga yang tertinggi mencapai 0,26 persen (ASEAN-Asia). Rendahnya pertambahan pertumbuhan PDB riil tersebut disebabkan oleh rendahnya tarif yang diterapkan negara Philipina (lihat tabel 6.5). Selain itu pula tingkat keterbukaan ekonomi negara Philipina juga terus menurun sejak tahun 2003 hingga tahun 2008 yakni 95 persen dan 67 persen (Swindi, 2010). Kedua hal inilah yang menyebabkan liberalisasi perdagangan tidak terlalu berdampak kepada pertambahan pertumbuhan PDB riil.

Thailand. Negara ini merupakan salah satu negara yang paling menikmati dampak dari liberalisasi perdagangan. Pertambahan pertumbuhan PDB riil negara Thailand berkisar antara 0,22 (ASEANIndia) dan 1,49 (ASEAN-Asia). Negara Thailand merupakan negara yang mengalami pertambahan pertumbuhan PDB riil tertinggi kedua di kawasan ASEAN. Beberapa penyebab hal tersebut adalah : pertama, tingginya tingkat keterbukaan ekonomi negara Thailand yang mencapai 132 persen. Kedua, relatif tingginya tarif impor yang diterapkan di Thailand. Ketiga, keberhasilan pemerintah Thailand dalam memperbaiki struktur ekonomi hingga relatif stabil paska krisis Asia 1997/1998, bahkan pertumbuhan ekonomi Thailand termasuk paling tinggi di kawasan ASEAN dalam kurun waktu satu dekade terakhir.

Vietnam. Dari kelima skema liberalisasi perdagangan, Vietnam merupakan negara yang paling tinggi mendapatkan mafaat dari liberalisasi perdagangan terutama terhadap pertambahan pertumbuhan ekonomi. Pertambahan pertumbuhan ekonomi Vietnam berkisar antara 0,28 persen (ASEAN-India) hingga 3,02 persen (ASEAN-Asia). Hal ini menujukkan bahwa Vietnam akan menjadi salah satu negara anggota ASEAN yang memiliki 
pertumbuhan ekonomi tertinggi. Hal ini sejalan dengan kebijakan ekonomi Vietnam yang semakin terbuka dimana tingkat keterbukaan ekonominya terus meningkat sejak tahun 2003 hingga tahun 2008 yakni 115 persen dan 157 persen

\subsection{Dampak Terhadap Investasi dan Konsumsi Masyarakat.}

Selain disebabkan oleh perbedaan besarnya tarif yang diterapkan sebelum liberalisasi dan tingkat keterbukaan ekonomi, peningkatan kuantitas PDB secara riil dengan besaran yang berbedabeda disebabkan oleh perbedaan peningkatan investasi dan konsumsi masyarakat.

Secara keseluruhan, penghapusan tarif impor mendorong peningkatan investasi dan konsumsi masyarakat di semua negara ASEAN dengan rata-rata peningkatan investasi tertinggi terjadi di skema ASEAN-Asia yang mencapai 13,61 persen. Demikian pula dengan pertumbuhan konsumsi masyarakat yang tumbuh tinggi dalam skema ASEAN-Asia . Adanya skema liberalisasi perdagangan di kawasan Asia juga mempunyai konsekuensi terhadap konsumsi (consumption effect). Secara teori, salah satu pengaruh pada konsumsi masyarakat adalah bergesernya garis Consumption Possibility Frontier (CPF) ke atas. Ini berarti bahwa adanya perdagangan membuat masyarakat bisa mengkonsumsi dalam jumlah yang lebih besar daripada sebelum adanya perdagangan. Dengan kata lain bahwa pendapatan riil masyarakat (yaitu pendapatan yang diukur dari berapa jumlah barang yang bisa dibeli oleh jumlah uang tersebut) meningkat dengan adanya perdagangan.

Dalam konteks negara-negara ASEAN, pertambahan konsumsi masyarakat terjadi di hampir semua negara dengan rata-rata peningkatan tertinggi terjadi pada skema ASEAN-Asia yang mencapai 2,52 persen.

Indonesia. Dalam semua skema liberalisasi perdagangan pertumbuhan investasi dan konsumsi masyarakat yang terjadi di Indonesia jauh lebih kecil dibandingkan dengan negara-negara ASEAN lainnya. Peningkatan investasi Indonesia berkisar antara 0,59 persen (ASEAN-India) hingga mencapai 1,69 persen (ASEAN-Asia). Ini menunjukkan bahwa daya tarik investasi di Indonesia lebih lemah dibandingkan dengan negaranegara lainnya. Hal ini diperkuat dengan data Global Competitiveness Index dalam World Economic Forum (2011), dimana peringkat Indonesia berada pada peringkat 44 jauh berada di bawah Malaysia dan Thailand yang masing-masing berada di peringkat 26 dan 38.

Demikian pula dengan konsumsi masyarakat yang menunjukkan bahwa konsumsi masyarakat di Indonesia hanya tumbuh antara 0,24 persen (ASEANJepang) dan 1,01 persen (ASEAN-Asia). Hal ini berarti peningkatan pertumbuhan konsumsi masyarakat di Indonesia lebih rendah dibandingkan rata-rata pertumbuhan konsumsi masyarakat di ASEAN. Dapat dipahami bahwa rendahnya pertumbuhan konsumsi masyarakat tersebut sejalan dengan relatif rendahnya tarif impor Indonesia sebelum diberlakukan liberalisasi sehingga tingkat harga barang-barang impor sudah relatif rendah.

Malaysia. Berdasarkan hasil analisa, peningkatan investasi di Malaysia merupakan salah satu yang paling tinggi di kawasan ASEAN dengan pertumbuhan berkisar antara 3,33 persen (ASEAN-India) hingga 12,2 persen (ASEAN-Asia). Tingginya investasi di Malaysia antara lain disebabkan pula dengan perubahan struktur industri dalam negerinya dari industri berbasis intensifikasi modal ke arah industri berbasis teknologi. Wie (2006) didukung oleh Atje et al (2005) menekankan bahwa cara yang ditempuh dalam meningatkan industri berbasis teknologi adalah dengan mengundang PMA (Penanaman Modal Asing).

Adapun pertumbuhan konsumsi negara Malaysia akan berkisar antara 0,21 
persen (ASEAN-Jepang) hingga 3,41 persen (ASEAN-China). Peningkatan konsumsi masyarakat ini tidak terlepas dari tingginya tarif bilateral yang diterapkan sebelum adanya liberalisasi sehingga masyarakat dapat menikmati harga barang yang lebih murah pasca dilaksanakannya liberalisasi perdagangan.

Singapura. Pertumbuhan investasi dan konsumsi masyarakat di Singapura relatif tidak terlalu besar. Hal ini sejalan dengan dampak dari peningkatan PDB riil mereka yang juga tidak terlalu tinggi. Pertumbuhan investasi Singapura berkisar antara 0,69 persen (ASEAN-Jepang) dan 2,09 persen (ASEAN-Asia).

Philipina. Dalam seluruh skema liberalisasi, ditemukan bahwa pertambahan investasi di Philipina tidaklah terlalu besar. Selain sejalan dengan dampaknya terhadap peningkatan PDB riilnya, peningkatan investasi yang relatif rendah tersebut disebakan pula hambatan-hambatan berinvestasi di Philipina. Berdasarkan hasil survei yang dilakukan oleh Bank Dunia tahun 2008 dari 178 negara, Philipina menempati peringkat ke 133 atau paling rendah dibandingkan dengan negaranegara ASEAN lainnya. Faktor utama penghambat investasi di Philipina adalah kondisi infrastruktur yang kurang memadai (Purwanto, 2006).

Adapun konsumsi masyarakat di Philipina akan tumbuh pada kisaran 0,13 persen (ASEAN-Asia) hingga 2,17 persen (ASEAN-China). Peningkatan konsumsi masyarakat ini tidak terlepas dari relatif rendahnya tarif bilateral yang diterapkan sebelum adanya liberalisasi sehingga dampaknya terhadap konsumsi masyarakat juga tidak terlalu besar.

Thailand. Berdasarkan hasil analisa, peningkatan investasi di Thailand merupakan yang paling tinggi di kawasan ASEAN dengan pertumbuhan berkisar antara 6,29 persen (ASEAN-India) hingga 34,9 persen (ASEAN-Asia). Selain disebaban karena liberalisasi perdagangan, peningkatan investasi di Thailand disebabkan pula oleh persepsi positif para investor melihat upaya pemerintah setempat dalam mewujudkan stabilitas dan sustainabilitas pertumbuhan ekonominya.

Vietnam. Pertumbuhan investasi di negara Vietnam relatif cukup tinggi dibandingkan dengan negara-negara ASEAN lainnya termasuk Indonesia. Pertumbuhan investasi negara Vietnam mencapai antara 6,08 persen (ASEANIndia) hingga 29,41 persen (ASEAN-Asia). Hal ini selain ditunjang oleh pertumbuhan ekonomi pula dengan peningkatan pertumbuhan PDB riil

Selain itu akibat dari relatif tingginya tarif impor sebelum diberlakukannya liberalisasi, pendapatan riil masyarakat meningkat setelah adanya penghapusan tarif impor sehingga masyarakat mampu membeli barang dengan lebih murah. Tingkat konsumsi masyarakat negara Vietnam meningkat cukup tinggi yaitu berkisar antara 0,43 (ASEAN-China) hingga 5,23 persen (ASEAN-Asia).

\subsection{Dampak Terhadap Kesejahteraan.}

Dengan bertambahnya pertumbuhan ekonomi yang didorong oleh peningkatan konsmsi masyarakat dan investasi maka akan berdampak pula pada peningkatan kesejahteraan. Selain itu, dengan penghapusan tarif impor masyarakat dapat memperoleh barang dengan harga yang relatif lebih murah (efek ini disebut trade creation effect).

Trade creation adalah penggantian produk domestik negara yang melakukan perjanjian liberalisasi perdagangan dengan produk impor yang lebih murah dari anggota lain. Jika seluruh sumber daya digunakan secara penuh dan negara melakukan spesialisasi perdagangan berdasarkan keunggulan komparatifnya, maka masing-masing negara akan memperoleh dampak positif berupa peningkatan kesejahteraan masyarakat karena memperoleh barang dengan harga yang relatif lebih murah.

Berdasarkan kelima skema liberalisasi, penghapusan tarif berdampak pada peningkatan kesejahteraan di semua 
negara anggota ASEAN dengan peningkatan tertinggi terjadi pada skema ASEAN-Asia .

Indonesia. Sejalan dengan peningkatan konsumsi masyarakat, investasi dan peningkatan ekonomi yang relatif tidak terlalu tinggi, peningkatan kesejahteraan akibat liberalisasi perdagangan bagi Indonesia juga relatif rendah dibandingkan negara-negara ASEAN lainnya. Pertambahan kesejahteraan bagi Indonesia berkisar antara US\$ 377,57 juta (ASEAN-Korea) dan US\$ 994,98 juta (ASEAN-Asia). Hasil studi Firdaus (2011) yang meneliti dampak dari liberalisasi perdagangan ASEAN Plus Three terhadap peningkatan kesejahteraan Indonesia juga menujukkan hal yang sama dimana Indonesia tidak termasuk negara ASEAN yang paling menikmati manfaat dari penghapusan tarif impor negaranegara di kawasan Asia.

Malaysia. Selain didorong oleh peningkatan investasi dan konsumsi masyarakat yang tinggi yang pada gilirannya mendorong pertumbuhan ekonomi, peningkatan kesejahteraan negara Malaysia juga didukung oleh rendahnya PDB deflator negara tersebut di semua skema liberalisasi. Rendahnya PDB deflator ditunjukkan pula dengan tingkat inflasi umum negara tersebut yang selalu rendah yang berarti masyarakat dapat memperoleh barang-barang dengan harga murah.

Peningkatan kesejahteraan Malaysia berkisar antara US\$ 504, 06 juta (ASEAN-India) hingga US\$ 1.296,94 juta (ASEAN-Asia). Sejalan dengan relatif tingginya peningkatan investasi, konsusi masyarakat dan pertambahan PDB riilnya, peningkatan kesejahteraan Malaysia juga termasuk yang tertinggi di ASEAN.

Philipina. Dalam semua skema liberalisasi, peningkatan kesejahteraan Philipina merupakan yang paling rendah di semua negara ASEAN yakni berkisar antara US\$ 144,62 juta (ASEAN-Asia) hingga US\$ 285,23 juta (ASEAN-China). Hal ini sejalan dengan berbagai studi terdahulu bahwa manfaat dari liberalisasi pada umumnya menumpuk pada negaranegara yang kondisi perekonomian makronya relatif lebih baik.

\section{Singapura.}

Peningkatan kesejahteraan negara Singapura berkisar antara US\$ 440,16 juta (ASEAN-Jepang) hingga US\$ 1.212,76 juta (ASEAN-China), dan merupakan salah satu yang tertinggi di kawasan ASEAN

Thailand. Seperti halnya tingginya peningkatan pertumbuhan PDB riil yang didukung oleh tingginya peningkatan investasi dan konsumsi masyarakat, tingkat kesejahteraan negara Thailand juga meningkat tinggi dan mencapai kisaran US\$ 942,41 juta (ASEAN-India) hingga US\$ 2.904,94 juta (ASEAN-Asia). Dapat disimpulkan bahwa negara Thailand menjadi salah satu negara yang paling banyak mendapat manfaat dengan adanya liberalisasi perdagangan di kawasan Asia. Ridwan (2011) dalam penelitiannya juga menujukkan bahwa integrasi ekonomi di kawasan Asia lebih memberikan manfaat kepada Thailand dibandingkan negaranegara lainnya di ASEAN.

Vietnam. Dalam semua skema terlihat bahwa liberalisasi perdagangan juga berdampak pada peningkatan kesejahteraan negara Vietnam antara yang terendah mencapai US\$ 226,24 juta (ASEAN-India) hingga yang tertinggi mencapai US\$ 1.615,39 juta (ASEANAsia).

Secara keseluruhan, hampir seluruh negara ASEAN mengalami peningkatan kesejahteraan tertinggi dalam skema liberalisasi ASEAN-Asia kecuali Singapura yang mencapai pertumbuhan kesejahteraan tertinggi dalam skema ASEAN-China. Hal ini sejalan dengan studi Ridwan (2011) dimana integrasi ekonomi yang terlalu luas justru membawa dampak kurang baik bagi perekonomina Singapura. Singapura lebih menempuh dan memperkuat jalur bilateral untuk mendukung kebijakannya di sektor perdagangan. 


\begin{abstract}
Gambaran lengkap dampak liberalisasi perdagangan terhadap pertambahan kesejahteraan di negara negara ASEAN dapat diihat pada tabel 7.4 berikut
\end{abstract}

\subsection{Dampak Terhadap PDB Deflator dan Terms of Trade (TOT).}

Selanjutnya, jika dilihat dari hasil simulasi penghapusan tarif juga berdampak terhadap PDB deflator atau tingkat inflasi. Meningkatnya PDB deflator di negara-negara ASEAN salah satunya karena masih tingginya tingkat ketergantungan beberapa komoditi impor dari negara negara mitra dagangnya sehingga bila ada kenaikan harga impor akibat kenaikan permintaan, kenaikannya akan mempengaruhi indeks harga umum. Secara umum hal tersebut mengartikan bahwa antar sesama negara ASEAN dan negara mitra dagang mengalami saling ketergantungan terhadap barang-barang impor dari sesama negara yang terlibat.

Adapun variabel Terms of Trade (TOT) atau kurs riil mencerminkan harga relatif barang-barang antara dua negara. Dari hasil semua simulasi, TOT negara ASEAN menjadi meningkat karena adanya penghapusan tarif impor. Kurs riil atau TOT tinggi mencerminkan barang-barang impor relatif lebih murah dan barangbarang domestik di negara-negara ASEAN relatif lebih mahal. Hal ini berarti dengan adanya penghapusan tarif impor maka tingkat daya saing negara ASEAN menurun dibanding dengan negara-negara mitra dagangnya.

Indonesia. Dalam seluruh skema liberalisasi, akan berdampak pada perambahan peningkatan inflasi dengan peningkatan antara 0,09 persen (ASEANJepang) dan 0,86 persen (ASEAN-Asia). Peningkatan pertambahan inflasi di Indonesia tidak terlau tinggi bila dibandingkan dengan negara-negara ASEAN lainnya. Hal ini sejalan dengan rendahnya tarif impor sebelum liberalisasi yang berdampak pada kenakan permintaan komoditi impor yang tidak terlalu tinggi yang pada akhirnya kenaikan harga secara umum dapat terjaga.

Dari hasil simulasi terlihat bahwa dengan ikutserta dalam liberalisasi perdagangan, salah satu tantangan terbesar adalah menjaga daya saing produk dalam negeri. Di semua skema liberalisasi, TOT Indonesia meningkat antara 0,08 persen (ASEAN-Jepang) hingga 0,60 (ASEANIndia). Secara teori peningkatan TOT yang lebih besar dibandingkan dengan TOT mitra dagang menujukkan daya saing produk dalam negeri menurun dibandingkan produk impor.

Sebagai contoh dalam skema liberalisasi ASEAN-China, TOT Indonesia meningkat sebesar 0,41 persen dan TOT negara China meningkat 0,19 persen. Artinya kurs riil Indonesia terapresiasi sebesar 0,41 persen dan mengakibatkan kenaikan impor yang lebih cepat dibandingkan kenaikan ekspor khususnya dari dan ke negara China. Dapat disimpulkan akibat dari kerjasama ASEAN-China, produk-produk China akan masuk lebih cepat ke Indonesia dibandingkan produk-produk Indonesia ke negara China.

Malaysia. Tingkat kenaikan PDB deflator di Malaysia juga relatif terjaga bahkan pada beberapa skema menunjukkan peningkatan pertumbuhan negatif dari PDB deflator. Hal ini sejalan dengan terjaganya daya saing produk dalam negeri yang tercermin dari rendahnya kenaikan TOT Malaysia.

Terjaganya PDB deflator dan tingkat daya saing produk dalam negeri merupakan hasil dari perencanaan pembangunan jangka pajang Malaysia (Mohammed, 2001) dimana sejak era 1980-an telah terjadi pengalihan orientasi pembangunan dari input driven economy menjadi productivity driven economy. Hal ini mendorong peningkatan total factor producivity (TFP) di Malaysia dari 1,8 pada kurun waktu tahun 1990 - 2000 menjadi 3,2 pada kurun waktu tahun 1991 -2010 . 
Philipina. Tingkat PDB deflator dan TOT negara Philipina juga meningkat namun dalam besaran yang lebih kecil dibandingkan dengan Indonesia. Peningkatan PDB deflator Philipina berkisar antara -0,2 persen (ASEAN-Asia) dan 0,32 persen (ASEAN-Korea). Adapun peningkatan nilai tukar Peso secara riil meningkat sebesar $-0,21$ persen atau mengalami depresiasi nilai tukar riil (ASEAN-Asia) hingga 0,32 persen (ASEAN-Korea). Sesuai dengan studi Ridwan (2011) nilai tukar Peso Philipina berpengaruh negatif dan signifikan terhadap kinerja ekspor dan impornya.

Singapura. Dalam semua skema liberalisasi, terlihat bahwa pertambahan PDB deflator dan TOT di Singapura walaupun meningkat cukup tinggi namun masih dalam batasan yang normal (dibawah 1 persen). Bakan dalam beberapa skema liberalisasi kenaikan TOT Singapura lebih rendah dibanding negara mitra dagangnya seperti Korea dan Jepang. Ini berarti daya saing produk dalam negeri Singapura tetap kuat ditengah derasnya arus masuk produk impor dari Korea dan Jepang.

Thailand. Dalam semua skema liberalisasi tingkat PDB deflator dan TOT negara Thailand mengalami peningkatan yang cukup tinggi. Kenaikan PDB deflator berkisar antara 1,18 persen (ASEAN-India) hingga 3,75 persen (ASEAN-Asia). Kenaikan PDB deflator tersebut tidak terlepas dari tingginya tarif impor sebelum liberalisasi. Ketika tarif impor dihapuskan maka konsumsi masyarakat Thailand meningkat pesat khususnya barang-barang impor sehingga dengan peningkatan permintaan akan meningkatkan pula harga barang-barang impor yang pada gilirannya meningkatkan harga secara umum.

Adapun kenaikan TOT di Thailand berkisar antara 0,57 persen (ASEAN- India) hingga 1,83 persen (ASEAN-Asia). Tingginya kenaikan TOT merupakan cerminan dari rendahnya daya saing produk domestik dibanding produk impor. Hal ini sesuai dengan tingginya permintaan barang impor yang tercermin pula dari tingginya PDB deflator.

Vietnam. Sejalan dengan fenomena di negara-negara ASEAN lainnya, PDB deflator dan TOT di negara Vietnam juga meningat walaupun tidak setinggi yang terjadi di negara Thailand. PDB deflator meningkat antara 0,38 persen (ASEAN-India) hingga 1,7 persen (ASEAN-Asia). Sedangkan TOT negara Vietnam meningkat antara 0,33 persen (ASEAN-India) hingga 0,87 persen (ASEAN-Asia).

\subsection{Dampak Terhadap Ekspor Bersih}

Pada simulasi terlihat bahwa neraca perdagangan semua negara mengalami penurunan. Peningkatan TOT yang disebabkan lebih tingginya harga ekspor dibandingkan harga impor menyebabkan impor lebih besar dibandingkan dengan ekspor. Dalam jangka panjang dengan adanya liberalisasi ini justru memperbaiki neraca perdagangan diantara sesama negara. Hal ini disebabkan pada kondisi awal sebelum diberlakukannya liberalisasi, neraca perdagangan di hampir seluruh negara yang terlibat sudah mengalami defisit yang jauh lebih besar. Berdasarkan kajian yang dilakukan oleh Firdaus (2011), defisit neraca perdagangan Indonesia sebelum diberlakukannya liberalisasi perdagangan ASEAN-China mencapai defisit US\$ -4,959 juta, setelah skema liberalisasi menjadi defisit US\$ 378,48 juta. Karena semakin kecilnya defisit neraca perdagangan, hal ini menunjukkan bahwa dengan adanya liberalisasi mampu memperbaiki kinerja perdagangan masingmasing negara yang terlibat.

Neraca perdagangan yang negatif juga merupakan signal bahwa peningkatan investasi dibiayai oleh tabungan. Secara teoritis, kenaikan permintaan investasi akan menurunkan tabungan bersih dan mengurangi persediaan nilai tukar domestik yang diinvestasikan ke luar negeri, sehingga kurs riil keseimbangan akan meningkat dan mengakibatkan kurs 
mengalami apresiasi, barang-barang domestik menjadi relatif lebih mahal terhadap barang luar negeri, dan ekspor netto turun. Pada gilirannya, hal ini mengakibatkan neraca perdagangan menjadi negatif.

Liberalisasi perdagangan ASEAN maupun Asia berdampak pada terhadap kinerja ekspor dan impor seluruh negara ASEAN. Berdasar hasil simulasi atas semua skema yang ada nampak bawa liberalisasi ASEAN-Asia lebih berpengaruh dibandingkan dengan skema lainnya. Hal ini menujukkan bahwa liberalisasi ASEAN dan negara-negara seperti China, Korea, Jepang dan India juga berpengaruh terhadap nilai ekspor dan impor negara-negara ASEAN namun nilainya relatif kecil.

Selain itu, hal ini juga menujukkan bahwa semakin luas integrasi ekonomi, akan semakin meningkatkan kinerja perdagangan negara-negara anggotanya. Penelitian Clarete et al (2002) tentang tingkat integrasi ekonomi yang tergabung dalam APEC, Uni Eropa dan NAFTA memberikan hasil yang sama. Artinya, integrasi ekonomi berdampak positif terhadap peningkatan perdagangan dunia.

\section{KESIMPULAN DAN IMPLIKASI KEBIJAKAN}

\subsection{Kesimpulan}

1. Berdasarkan hasil analisa ditemukan bahwa dalam seluruh skema liberalisasi ASEAN tingkat kesejahteraan, PDB riil, tingkat harga mengalami peningkatan bagi Indonesia dan di sebagian besar negara-negara lain di kawasan ASEAN dan negaranegara yang terlibat dalam skema liberalisasi tersebut. Thailand menjadi negara di kawasan ASEAN yang paling banyak menikmati manfaat dari liberalisasi perdagangan. Hal ini didukung pula oleh tingkat keterbukaan ekonominya yang mencapai rata-rata 122,3 persen pada periode 2003-2008.
2. Bagi Indonesia khususnya, dampak positif dari liberalisasi perdagangan terhadap kinerja ekonomi makro masih tergolong rendah. Hal ini menunjukkan salah satunya masih rendahnya efisiensi produk domestik. Adapun negara-negara maju seperti China dan Korea tetap mendapatkan manfaat yang paling besar dengan adanya liberalisasi perdagangan dibandingkan negara-negara berkembang lainnya.

\subsection{Saran Kebijakan}

1. Berdasarkan hasil analisa dari lima skema liberalisasi diatas, maka bagi Indonesia khususnya perlu kiranya ditingkatkan daya saing domestik. Perbaikan kualitas infrastruktur yang mendorong investasi dan ekspor (infrastruktur listrik, transportasi) harus terus dilakukan didorong dengan upaya-upaya untuk menghilangkan ekonomi biaya tinggi dan pelaksanaan good govenance.

2. Guna mendapatkan menfaat yang lebih tinggi, Pemerintah harus memiliki komitmen untuk membuka perdagangan bagi sektor yang berdaya saing sedangkan yang belum memiliki dayasaing perlu mendapat dukungan untuk pengembangan kapasitas kelembagaan ekspor seperti memfasilitasi promosi dan usaha membangun kepercayaan internasional. Selain itu perlu pula dipertimbangkan kesepakatan-kesepakatan yang lebih luas daripada semata-mata perdagangan barang yakni yang berhubungan dengan perdagangan jasa, hak atas kekayaan intelektual dan lainnya.

\section{DAFTAR PUSTAKA}

Darwanto, H. 1997. Trade Liberalization in Indonesia: Impacts and Issues. The Indonesian Quarterly Vol. 25 (2), pp: 110-127. 
Feridhanusetyawan, T. dan Y. Rizal. 1998. Liberalisasi Perdagangan Dunia: Bagaimana Manfaatnya bagi Association of Southeast Asian Nations (ASEAN)? Analisis Centre for Strategic and International Studies (CSIS) Vol. 27 No. 3, pp: 258-278.

Hadi, PU.2003. Marketing Policy to Improve Competitiveness pf Agricultural Commodities Facing Trade Liberalization. Analisis Kebijakan Pertanian, Volume 1(2). Juni. Puslitbang Sosial Ekonomi Pertanian, Bogor

Haryadi, 2008. Dampak Liberalisasi Sektor Pertanian Terhadap Perekonomian Negara Maju dan Berkembang, Disertasi, Institut Pertanian Bogor.

Nayyar, Deepak. 1997. Globalization: The Game, The Players and The Rules. The Political Economy of Globalization, Kluwer Academic Publishers, Dordrecht.

Oktaviani, R. 2000. The Impact of Trade Liberalization on Indonesian Economy and its Agricultural Sector, Dissertation, Department of Agricultural Economics, University of Sydney
Oktaviani, R. et al, 2007. Perhitungan Penerimaan Bea Masuk Berdasarkan Kebijakan tarif dalam Skema Umum dan Skema Free Trade Area dan Evaluasi Dampak Kebijakan tarif Bea masuk dalam Skema ASEAN-China Free Trade Area dan ASEAN-Korea terhadap Pendapatan Negara. Departemen Keuangan, Jakarta.

Ratnawati, A. 1996. Dampak Kebijakan Tarif Impor dan Pajak Ekspor terhadap Kinerja Perekonomian, Sektor Pertanian dan Distribusi Pendapatan di Indonesia: Suatu Pendekatan Model Keseimbangan Umum. Disertasi Doktor. Program Pascasarjana, Institut Pertanian Bogor.

Tze, Ker Sin. 2005. Comparative Economic Structure and Performance in Taiwan and

Singapore.http://www.rchss.sinica.edu .tw/capas/publication/newsletter/N28/ 28_03_02.pdf

Wijaya, A. 2000. Dampak Liberalisasi Perdagangan terhadap Kinerja Ekonomi Indonesia: Suatu Pendekatan Makroekonometrika, Disertasi, Institut Pertanian Bogor 


\section{LAMPIRAN}

\begin{tabular}{|c|c|c|c|c|c|c|c|c|}
\hline \multirow{9}{*}{ 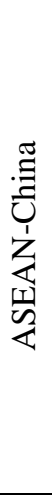 } & \multicolumn{8}{|c|}{ Dampak Liberalisasi (\%) } \\
\hline & & $\begin{array}{c}\text { PDB } \\
\text { Riil }\end{array}$ & $\begin{array}{c}\text { PDB } \\
\text { Deflator }\end{array}$ & TOT & $\begin{array}{c}\text { Kesejahteraan } \\
\text { (US\$ Juta) }\end{array}$ & $\begin{array}{c}\text { Ekspor } \\
\text { Bersih } \\
\text { (US\$ Juta) }\end{array}$ & Investasi & Konsumsi \\
\hline & Indonesia & 0,09 & 0,71 & 0,41 & 591,4 & $-378,48$ & 1,3 & 0.56 \\
\hline & Malaysia & 0,24 & 0,57 & 0,42 & 1.105 .79 & $-586,18$ & 6,47 & 3.41 \\
\hline & Philipina & 0,23 & 0,27 & 0,16 & 285,23 & $-266,99$ & 2,3 & 2.17 \\
\hline & Thailand & 0,45 & 2,45 & 1,27 & $1.059,58$ & -4.91948 & 13,74 & 2.29 \\
\hline & Singapura & $-0,01$ & 2,01 & 0,75 & $1.212,76$ & $-217,74$ & 2,09 & -0.12 \\
\hline & Vietnam & 1,34 & 0,74 & 0,47 & 741,69 & -2.10515 & 14,59 & 0.43 \\
\hline & China & 0,04 & 0,37 & 0,19 & $1.888,12$ & $-706,61$ & 0.33 & -0.2 \\
\hline & Indonesia & 0,06 & 0,35 & 0,25 & 377,57 & $-181,38$ & 0,66 & 0,44 \\
\hline ठே & Malaysia & 0,37 & $-0,02$ & 0,07 & 754,14 & $-445,63$ & 4,1 & 0,37 \\
\hline$\frac{1}{7}$ & Philipina & 0,16 & 0,32 & 0,17 & 224,24 & $-129,76$ & 1,23 & 0,54 \\
\hline$\frac{1}{4}$ & Thailand & 0,34 & 1,42 & 0,7 & 1.262 .72 & $-3063,64$ & 8,53 & 2,07 \\
\hline$\sqrt[5]{4}$ & Singapura & $-0,03$ & 1,17 & 0,44 & 682,82 & $-125,56$ & 1,19 & 1,23 \\
\hline & Vietnam & 0,78 & 0,76 & 0,5 & 504,27 & $-1571,87$ & 10,89 & 1,71 \\
\hline & Korea & 0,21 & 0,71 & 0,45 & $2.556,78$ & $-302,81$ & 0,72 & 0,92 \\
\hline & Indonesia & 0,12 & 0,09 & 0,08 & 403.43 & $-328,92$ & 1,01 & 0,24 \\
\hline జิ & Malaysia & 0,63 & $-0,46$ & $-0,08$ & $1.003,39$ & $-830,1$ & 5,97 & 0,21 \\
\hline$\stackrel{2}{r}$ & Philipina & 0,18 & 0,18 & 0,08 & 199,09 & $-175,83$ & 1,58 & 0,42 \\
\hline 4 & Thailand & 1,04 & 2,49 & 1,27 & $1.966,75$ & -8.909 & 24,04 & 4,34 \\
\hline$\sqrt{1}$ & Singapura & $-0,03$ & 0,73 & 0,29 & 440,16 & -58 & 0,69 & 0,76 \\
\hline & Vietnam & 0,72 & 0,91 & 0,64 & 528,67 & $-1546,78$ & 10,78 & 1,82 \\
\hline & Jepang & 0,03 & 0,49 & 0,46 & $2.556,78$ & $-577,21$ & 0,16 & 0,53 \\
\hline & Indonesia & 0,05 & 0,86 & 0,591 & 607,47 & $-44,06$ & 0,59 & 0,96 \\
\hline$\ddot{ت}$ & Malaysia & 0,04 & 0,39 & 0,251 & 504,06 & $-299,93$ & 3,33 & 0,44 \\
\hline 㝋 & Philipina & 0,15 & 0,18 & 0,0961 & 181,85 & $-118,98$ & 1,07 & 0,37 \\
\hline$\underset{\mathbb{1}}{\mathbb{1}}$ & Thailand & 0,22 & 1,18 & 0,5734 & 942,41 & $-2.240,34$ & 6,29 & 1,62 \\
\hline$\frac{\pi}{4}$ & Singapura & $-0,04$ & 1,5 & 0,558 & 863,53 & $-167,56$ & 1,54 & 1,58 \\
\hline & Vietnam & 0,28 & 0,38 & 0,326 & 228,64 & $-883,21$ & 6,08 & 0,73 \\
\hline & India & 0.34 & -0.63 & -0.31 & $1,795.03$ & $-435,99$ & 0,35 & $-0,36$ \\
\hline & Indonesia & 0,19 & 0,74 & 0,52 & 994,98 & $-444,1$ & 1,69 & 1,01 \\
\hline & Malaysia & 1,16 & $-0,23$ & 0,16 & $1,296.94$ & $-1.392,73$ & 12,2 & 1,07 \\
\hline & Philippines & 0,26 & $-0,2$ & $-0,21$ & 144,62 & $-304,15$ & 2,46 & 0,13 \\
\hline$\cdot \frac{\pi}{5}$ & Thailand & $\begin{array}{c}1,49 \\
-\end{array}$ & 3,75 & 1,83 & $2.904,94$ & $-12902,67$ & 34,9 & 6,39 \\
\hline Z & Singapore & 0,001 & 1,21 & 0,47 & 784,57 & $-43,91$ & 1,0 & 1,31 \\
\hline 넹 & Vietnam & 3,02 & 1,7 & 0,87 & $1.615,39$ & $-4222,81$ & 29,41 & 5,23 \\
\hline$<$ & China & 0,22 & 0,04 & $-0,44$ & $1.706,95$ & $-5784,24$ & 1,31 & 0,33 \\
\hline & Japan & 0,06 & 1,38 & 1,26 & $10.066,14$ & $-3826,79$ & 0,62 & 1,47 \\
\hline & Korea & 0,48 & 1,82 & 0,94 & 5563,96 & $-2567,19$ & 2,7 & 2,24 \\
\hline & HongKong & 0,004 & 1,73 & 1,13 & $1.350,17$ & 374,61 & 0,64 & 1,81 \\
\hline & Taiwan & 0,43 & 1,78 & 0,84 & $3.227,78$ & $-80,75$ & 3,46 & 2,3 \\
\hline & India & 0,41 & $-1,49$ & $-0,78$ & $1.674,69$ & $-585,83$ & 0,69 & $-1,13$ \\
\hline
\end{tabular}

